\title{
Gene Expression Profiling of IL-17A-Treated Synovial Fibroblasts from the Human Temporomandibular Joint
}

\author{
Toshio Hattori, ${ }^{1}$ Naomi Ogura, ${ }^{1,2}$ Miwa Akutsu, ${ }^{1,2}$ Mutsumi Kawashima, \\ Suguru Watanabe, ${ }^{1}$ Ko Ito, ${ }^{1,2}$ and Toshirou Kondoh ${ }^{1,2}$ \\ ${ }^{1}$ Department of Maxillofacial Surgery, Nihon University School of Dentistry at Matsudo, Matsudo, Chiba 271-8587, Japan \\ ${ }^{2}$ Research Institute of Oral Science, Nihon University School of Dentistry at Matsudo, Matsudo, Chiba 271-8587, Japan \\ Correspondence should be addressed to Toshirou Kondoh; kondo.toshiro@nihon-u.ac.jp
}

Received 19 August 2015; Revised 11 November 2015; Accepted 17 November 2015

Academic Editor: Claudia Cocco

Copyright (C) 2015 Toshio Hattori et al. This is an open access article distributed under the Creative Commons Attribution License, which permits unrestricted use, distribution, and reproduction in any medium, provided the original work is properly cited.

Synovial fibroblasts contribute to the inflammatory temporomandibular joint under pathogenic stimuli. Synovial fibroblasts and $\mathrm{T}$ cells participate in the perpetuation of joint inflammation in a mutual activation feedback, via secretion of cytokines and chemokines that stimulate each other. IL-17 is an inflammatory cytokine produced primarily by Th17 cells which plays critical role in the pathogenesis of numerous autoimmune and inflammatory diseases. Here, we investigated the roles of IL-17A in temporomandibular joint disorders (TMD) using genome-wide analysis of synovial fibroblasts isolated from patients with TMD. IL-17 receptors were expressed in synovial fibroblasts as assessed using real-time PCR. Microarray analysis indicated that IL-17A treatment of synovial fibroblasts upregulated the expression of IL-6 and chemokines. Real-time PCR analysis showed that the gene expression of IL-6, CXCL1, IL-8, and CCL20 was significantly higher in IL-17A-treated synovial fibroblasts compared to nontreated controls. IL-6 protein production was increased by IL-17A in a time- and a dose-dependent manner. Additionally, IL-17A simulated IL-6 protein production in synovial fibroblasts samples isolated from three patients. Furthermore, signal inhibitor experiments indicated that IL-17-mediated induction of IL-6 was transduced via activation of NFkB and phosphatidylinositol 3-kinase/Akt. These results suggest that IL-17A is associated with the inflammatory progression of TMD.

\section{Introduction}

The temporomandibular joint (TMJ) is one of the most complex and active joints in the human body, playing an important role in functions such as jaw motion speaking, chewing, and swallowing. Patients with temporomandibular disorders (TMD) most frequently present with pain, limited mandibular motion, and TMJ sounds. Inflammatory factors contribute to both inflammatory and degradative pathways associated with the progression of the pathological condition in the joints [1-3]. These inflammatory factors have been detected in the synovial fluids and/or tissues from patients with intracapsular pathological conditions of TMJ such as disc displacement (DD), internal derangement (ID), and/or osteoarthritis (OA) [1,2].

Synovitis, an inflammatory disorder of the synovial membrane, frequently accompanies ID and/or OA in TMJ $[4,5]$ and has been suggested to be a key feature of intracapsular pathological conditions of TMJ [6]. The synovial membrane lines all of the intra-articular structures, except for the articular cartilage of the eminence, fossa and mandibular condyle, and the articular disc [7]. The lining layer of synovial tissue is composed of fibroblast-like cells and macrophagelike cells and overlies loose connective tissue of the synovial sublining that contains blood vessel sublining fibroblasts and leukocytes. In orthopedics, synovial fibroblasts that are producing a number of putative mediators of inflammation and tissue degradation [8-10] and other immune cells communicate with one another in a unique inflammatory microenvironment [9]. An understanding of the molecular mechanisms that underlie the activities of these factors may contribute to an understanding of the pathogenesis of TMD; however, little is known about the molecular mechanisms that underlie the development of the pathological condition in TMJ. 
Interleukin- (IL-) 17 is secreted primarily by active Th17 cells, and IL-17s and IL-17 receptors play an important role in numerous autoimmune and inflammatory diseases [11, 12]. The IL-17 family consists of six family members of varying homology and function: IL-17A (commonly called IL-17), IL-17B, IL-17C, IL-17D, IL-17E (also called IL-25), and IL$17 \mathrm{~F}[13,14]$. The IL-17 receptor (IL-17R) family includes five members (IL-17RA to IL-17RE) [13, 14]; both IL-17A and IL$17 \mathrm{~F}$ bind to the same IL-17 receptor complex consisting of the receptor subunits IL-17RA and IL-17RC [13, 14]. IL-17 has been implicated in progression of arthritis in rheumatoid arthritis (RA) and OA. IL-17 was detectable in serum and knee synovial fluid samples from patients with $\mathrm{OA}$ and $\mathrm{RA}$, and a positive association was found between the IL-17 concentration and the disease severity and/or activity $[15,16]$. In vitro experiments with human cells identified IL-17A as a contributor to the promotion of synovial hyperplasia, synoviocyte invasion, cartilage degradation, and angiogenesis [17-20]. The pathogenic potential of IL-17A in inflammatory arthritis has also been reported in studies involving neutralization of IL-17A and in IL-17A-deficient mice [21].

Recently, IL-17 was also detected in synovial fluid from the TMJ with ID and OA [22]; however its role has not been studied in TMD. We isolated human synovial fibroblasts from the synovial tissue of patients with intracapsular pathological conditions of TMJ and then examined the gene expression profile of these cells when treated with IL-17A. The aim of this study was to investigate the roles of IL-17A in the pathogenesis of TMD.

\section{Materials and Methods}

2.1. Isolation and Culture of Synovial Fibroblasts. Human synovial tissue was obtained from three patients (TMJ1-3) who underwent arthroscopy for ID or open TMJ surgery for OA (TMJ1, female, age: 23 years, used for the oligonucleotide microarray analysis, real-time PCR, and ELISA. TMJ2, female, age: 26 years, used for ELISA. TMJ3, male, age 59 years, used for ELISA). All patients provided informed consent for the surgery and for the use of their tissue specimens for research purposes. The isolation of, primary culture of, and experimentation with synoviocytes were performed according to the guidelines established by the Institutional Review Board of Nihon University School of Dentistry at Matsudo (Ethics Committee Registration Number: EC10037).

Human synovial fibroblasts isolated from the synovial tissues of patients with intracapsular pathological conditions of TMJ (synovial fibroblasts) were prepared using the outgrowth method previously reported by Ogura et al. [23]. In brief, synovial tissue samples were washed with phosphatebuffered saline (PBS), minced, placed in a $35 \mathrm{~mm}$ tissue culture dish, and covered with a sterilized glass coverslip. The culture medium used was Ham's F12 (Wako, Osaka, Japan) supplemented with $10 \%$ fetal bovine serum (FBS) (Cell Culture Technologies, Gravesano, Switzerland), $100 \mu \mathrm{g} / \mathrm{mL}$ penicillin G (Meiji, Tokyo, Japan), $100 \mu \mathrm{g} / \mathrm{mL}$ kanamycin sulfate (Meiji), and $250 \mathrm{ng} / \mathrm{mL}$ Fungizone (Gibco, Grand Island, NY, USA). The medium was changed twice per week.
Confluent SFCs were detached with $0.025 \%$ trypsin (Gibco) and $0.02 \%$ EDTA in PBS and were then subcultured in Ham's F12 supplemented with 10\% FBS and antibiotics. For the experiments, FLSs obtained from passages 6 to 8 were used.

2.2. Total RNA Extraction. Confluent-stage synovial fibroblasts were cultured in medium containing 2\% FBS for $24 \mathrm{~h}$ and were then stimulated with or without $10 \mathrm{ng} / \mathrm{mL}$ IL-17A (PeproTech Inc., Rocky Hill, NJ, USA) for various lengths of time. Total cellular RNA from synovial fibroblasts was extracted using the RNeasy Mini Kit (Qiagen, Valencia, CA, USA) and was then stored at $-80^{\circ} \mathrm{C}$ until use.

2.3. DNA Microarray Analysis. Total RNA samples from synovial fibroblasts treated with IL-17A $(10 \mathrm{ng} / \mathrm{mL})$ for $4 \mathrm{~h}$ and from untreated control samples were profiled on a SurePrint G3 Human Gene Expression 8x60K v2 Microarray (Agilent Technologies Inc., Santa Clara, CA, USA), according to Agilent protocols. The array was scanned using an Agilent DNA Microarray Scanner. Gene expression analysis of the DNA microarray was performed using GeneSpring GX software (Agilent). Data were normalized using raw data from each array as a reference. Changes in gene expression were determined by comparing the normalized intensities for untreated cells with those of IL-17A-treated cells. The microarray data have been deposited in the National Center for Biotechnology Information Gene Expression Omnibus (GEO Series GSE74668; http://www.ncbi.nlm.nih.gov/geo/).

2.4. Signaling Pathway Analysis. Biologically relevant pathways of IL-17A-responsive genes were constructed using Ingenuity Pathway Analysis (IPA) (Ingenuity Systems, http:// www.ingenuity.com/, Redwood City, CA, USA). A dataset of the gene accession numbers and gene expression ratios (IL-17A-treated/control) of greater than 2-fold intensity as determined by the GeneSpring GX software program were uploaded into the IPA. Each gene identifier was mapped to its corresponding gene object in the Ingenuity Pathway Knowledge Base. The uploaded genes, called focus genes, were overlaid onto a global molecular network developed from information contained in the Ingenuity Pathway Knowledge Base. The analysis in IPA identifies relationships, mechanisms, functions, and pathways relevant to a dataset.

\subsection{Real-Time Polymerase Chain Reaction (Real-Time PCR).} Complementary DNA was synthesized from total RNA using a GeneAmp RNA PCR Kit (Thermo Fisher Scientific Inc., Waltham, MA, USA). Real-time PCR was performed using a DyNAmo SYBR Green qPCR Kit (Thermo Fisher Scientific Inc.). The PCR mixture $(20 \mu \mathrm{L})$ contained 20 pmol forward and reverse primers and $2 \mu \mathrm{L}$ cDNA. Amplification was performed using a DNA Engine Opticon 1 (Bio-Rad, Hercules, CA, USA), with preheating at $95^{\circ} \mathrm{C}$ for $10 \mathrm{~min}$, followed by $40 \mathrm{cycles}$ of $94^{\circ} \mathrm{C}$ for $15 \mathrm{~s}, 55^{\circ} \mathrm{C}$ for $30 \mathrm{~s}$, and $72^{\circ} \mathrm{C}$ for $30 \mathrm{~s}$. The genes analyzed in this study were examined for their relative expression to their respective control by using the $\Delta \Delta \mathrm{C}_{\mathrm{T}}$ method [24]. All analyses were performed in five 
TABle 1: Primers used for PCR analysis of genes.

\begin{tabular}{|c|c|c|}
\hline Gene & Primers & Amplicon size (bp) \\
\hline \multirow{2}{*}{ IL-6 } & F: 5'-AGC AAA GAG GCA CTG GCA GAA-3' & \multirow{2}{*}{331} \\
\hline & R: 5'-TTG TCA TGT CCT GCA GCC ACT-3' & \\
\hline \multirow{2}{*}{ CCL20 (MIP-3 $\alpha)$} & F: $5^{\prime}$-GCA AGC AAC TTT GAC TGC TG-3' & \multirow{2}{*}{342} \\
\hline & R: $5^{\prime}$-CAA GTC CAG TGA GGC ACA AA- $3^{\prime}$ & \\
\hline \multirow{2}{*}{ CXCL1 (GRO- $\alpha)$} & F: 5'-TGC AGG GAA TTC ACC CCA AG-3' & \multirow{2}{*}{229} \\
\hline & R: 5'-CAG GGC CTC CTT CAG GAA CA-3' & \\
\hline \multirow{2}{*}{ IL-8 (CXCL8) } & F: $5^{\prime}$-ACT CCA AAC CTT TCC ACC CCA-3' & \multirow{2}{*}{129} \\
\hline & R: $5^{\prime}$-TTT CCT TGG GGT CCA GAC AGA-3' & \\
\hline \multirow{2}{*}{ IL-17RA } & F: 5'-TTC ATT CCT ATG CCT GAG TC-3' & \multirow{2}{*}{204} \\
\hline & R: 5'-TAC AGT AAG TGG CTC GAC CT- $3^{\prime}$ & \\
\hline \multirow{2}{*}{ IL-17RB } & F: 5'-CCT CCG AGT AGA ACC TGT TA-3' & \multirow{2}{*}{200} \\
\hline & R: $5^{\prime}$-GTC TGG TCT GAG TCT GGA AG-3' & \\
\hline \multirow{2}{*}{ IL-17RC } & F: 5'-GGA CAA ATA CAT CCA CAA GC-3' & \multirow{2}{*}{192} \\
\hline & R: $5^{\prime}$-GAG TCA TCG GCT GAG TAG AG-3' & \\
\hline \multirow{2}{*}{ IL-17RD } & F: 5'-TGT GCC TTA GAG CAG GTG TG-3' & \multirow{2}{*}{204} \\
\hline & R: 5'-TGT GCT TGG AAG GGA AAG TC-3' & \\
\hline \multirow{2}{*}{ IL-17RE } & F: $5^{\prime}$-GGG TCT CTC ACA TCC TGG AA- $3^{\prime}$ & \multirow{2}{*}{207} \\
\hline & R: 5'-CCT CAG GAA GGG AAT GAT GA-3' & \\
\hline \multirow{2}{*}{ GAPDH } & F: $5^{\prime}$-ATC ACC ATC TTC CAG GAG-3' & \multirow{2}{*}{318} \\
\hline & R: 5'-ATG GAC TGT GGT CAT GAG-3' & \\
\hline
\end{tabular}

IL-6, interleukin-6; CCL20, chemokine (CC motif) ligand 20; CXCL1, chemokine (CXC motif) ligand 1; IL-8, interleukin-8; IL-17R (A-E), interleukin-17 receptor (A-E); GAPDH, glyceraldehyde-3-phosphate dehydrogenase; F, forward primer; R, reverse primer.

replicates, and the results were confirmed by five independent experiments.

PCR fragments were electrophoresed on 1.5\% agarose gels, followed by staining with Midori Green Direct (NIPPON Genetics, Tokyo, Japan) and examination of fragment sizes. The primer sequences used for the real-time PCR analysis are shown in Table 1.

2.6. Enzyme Linked Immunosorbent Assay (ELISA). Synovial fibroblasts were plated at a density of $5 \times 10^{4}$ cells per well in 24-well plates with Ham's F12 medium containing $10 \%$ FBS. Confluent cells were cultured for $24 \mathrm{~h}$ in the same medium containing $2 \%$ FBS. After incubation with IL-17A for the appropriate length of time, culture supernatants were collected and stored at $-80^{\circ} \mathrm{C}$ until use. The kinetics of IL-6 protein production was examined in control samples and in synovial fibroblasts incubated with IL-17A $(10 \mathrm{ng} / \mathrm{mL})$ for $4,8,12$, and $24 \mathrm{~h}$. To examine the dose dependency of IL- 6 protein expression, the cells were treated with IL-17A at concentrations of 1,10 , and $50 \mathrm{ng} / \mathrm{mL}$ for $24 \mathrm{~h}$. The IL6 levels in the conditioned medium were measured using ELISA kit (R\&D Systems, McKinley, MN, USA), according to the manufacturer's protocol. The ELISA experiments were independently performed six times.

2.7. Inhibition of IRAK 1/4, PI3K, TAK1, and IKK $\beta$. Synovial fibroblasts were plated at a density of $5 \times 10^{4}$ cells per well in 24-well plates with Ham's F12 medium containing 10\% FBS. Confluent cells were cultured for $24 \mathrm{~h}$ in medium containing $2 \%$ FBS. The inhibition experiments were performed using the following inhibitors: Interleukin-1 Receptor-AssociatedKinase-1/4 (IRAK-1/4) inhibitor $(20 \mu \mathrm{M})$ (Merck KGaA, Darmstadt, Germany), the phosphoinositide 3-kinase (PI3K) inhibitor LY294002 $(20 \mu \mathrm{M})$ (Merck KGaA), the transforming growth factor- $\beta$-activated kinase 1 (TAK1) inhibitor (5z)7-Oxozeaenol $(1 \mu \mathrm{M})$ (Merck KGaA), and the inhibitor of the $\mathrm{NF} \kappa \mathrm{B}$ kinase $\beta$ subunit (IKK $\beta)$ inhibitor PS-1145 $(10 \mu \mathrm{L})$ (Cayman Chemical, Ann Arbor, MI, USA). The cells were pretreated with the inhibitor reagents for $30 \mathrm{~min}$, followed by incubation with IL-17 $(10 \mathrm{ng} / \mathrm{mL})$. After $8 \mathrm{~h}$, the culture supernatants were collected and stored at $-80^{\circ} \mathrm{C}$ until use. The inhibitor effect was calculated as $100-$ [(IL-6 production with IL-17 in the presence of the inhibitor)/(IL- 6 production with IL-17) $\times 100$ ]. The IL-6 levels in the conditioned medium were measured using ELISA kit (R\&D systems).

2.8. Statistical Analysis. The data are expressed as means \pm standard deviations (SD) and were analyzed using one-way analysis of variance (ANOVA). Post hoc analyses were carried out using the Student-Newman-Keuls (SNK) Multiple Comparison Test. $P<0.05$ and $P<0.01$ were considered to indicate significant differences.

\section{Results}

3.1. Expression of IL-17 Receptor Family Members in Synovial Fibroblasts. Before examination of the functional effects of IL-17A (which was used as a typical IL-17) in synovial fibroblasts, we first analyzed the expression of IL-17R family members A-E in synovial fibroblasts using real-time PCR. All 


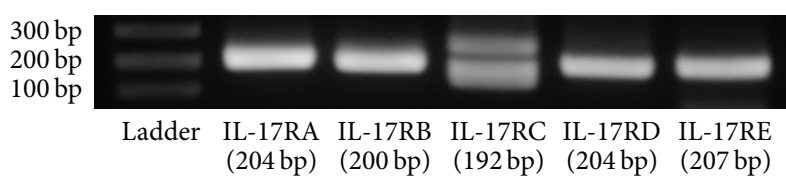

FIgURE 1: The expression of IL-17 receptors in synovial fibroblasts. IL-17RA, IL-17RB, IL-17RC, IL-17RD, and IL-17RE mRNA levels in synovial fibroblasts were analyzed using real-time PCR. The PCR products were electrophoresed through an agarose gel.

IL-17R family members were expressed in synovial fibroblasts (Figure 1). IL-17A signals through a heterodimeric receptor complex composed of IL-17RA and IL-17RC [14]. These data therefore suggested that IL-17A signaling is transduced in synovial fibroblasts.

3.2. Microarray Analysis of Synovial Fibroblasts. We next analyzed the gene expression profiles of synovial fibroblasts that were treated with or without IL-17A to determine the mechanisms underlying its effects in pathological conditions of TMJ. Of the 50,739 genes on the DNA microarray, 27,583 genes were expressed in synovial fibroblasts, and the expression of these genes was compared between nontreated control cells and IL-17A-treated cells. Genes that showed a greater than twofold difference in expression between IL-17Atreated and control cells were further analyzed. A total of 1,710 genes showed greater than 2-fold changes in expression with IL-17 treatment; the expressions of 389 of these genes were upregulated, and the expressions of 1,321 of these genes were downregulated (Figure 2). The 1,710 IL-17-responsive genes were categorized based on the gene ontology of molecular function using GeneSpring software. Many upregulated genes were categorized functionally in the ligands of receptors such as chemokines, growth factors, and cytokines that are regulators associated with inflammation and immunity. In contrast, several downregulated genes were categorized as receptors for ligands (Table 2).

3.3. IL-17A Signaling Pathway Analysis. To investigate the existence of biologically relevant pathways for IL-17Aresponsive genes in synovial fibroblasts, we uploaded a dataset of IL-17A-responsive genes containing gene identifiers and corresponding fold change values obtained by the DNA microarray analysis into the IPA system as focus genes. The 1,710 IL-17A-responsive genes were categorized based on gene ontology (data not shown). The most highly related category by diseases and disorders was the inflammatory response, followed by connective tissue disorders and immunological disease. The related categories by molecular function were cellular growth and proliferation, cell to cell signaling and interaction, and cellular movement.

Next, the IL-17A-responsive genes were arranged in molecular networks using the IPA system, which linked these genes in a graphical representation of the canonical pathways. The illustration in Figure 3(a) shows the canonical pathway for "roles of IL-17A in arthritis," which are key molecules in inflammation and destruction in arthritis. Nodes are shown as genes and/or gene products; the red nodes show genes

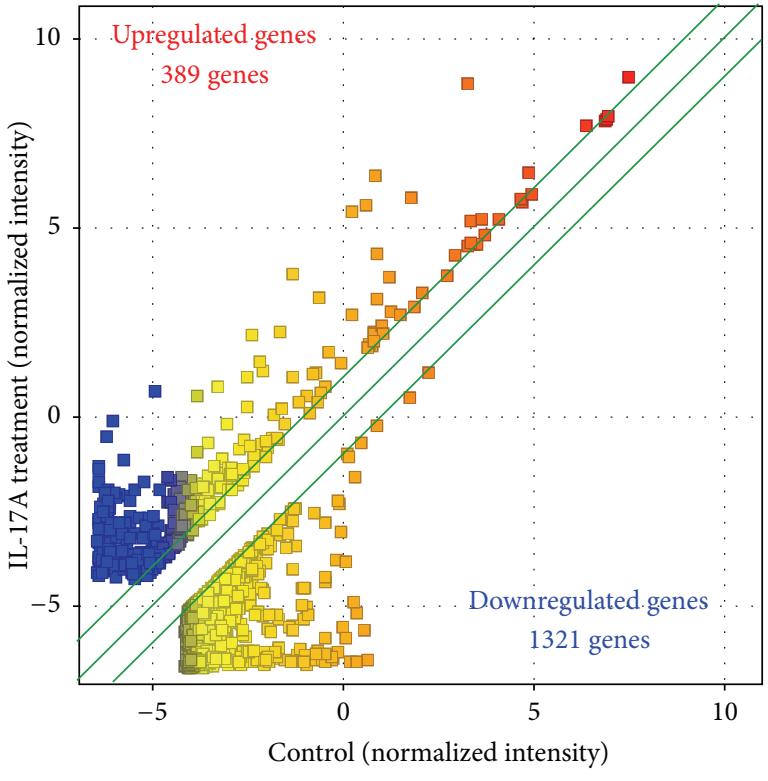

FIGURE 2: Scatter plots of microarray analysis. Of the 50,739 genes on the DNA microarray, the 27,583 genes that were expressed in synovial fibroblasts were compared between synovial fibroblasts treated with IL-17A and nontreated control. Of these 27,583 genes, 1,710 genes (389 upregulated genes and 1321 downregulated genes) showed a greater than twofold difference between IL-17A-treated and control cells.

upregulated by IL-17A in synovial fibroblasts by the microarray analysis data. The expression of numerous chemokines was upregulated by IL-17A treatment; in contrast, IL-17RA and IL-17RC were constitutively expressed and their expression in synovial fibroblasts did not change in response to IL17A. IL-17A upregulated genes such as IL-6 and chemokines are regulated by $\mathrm{NF} \kappa \mathrm{B}$ although the expression of $\mathrm{NF} \kappa \mathrm{B}$ complex molecules was not responsive to IL-17A (Figure 3(b)).

3.4. Time Course of IL-17A-Induced Gene Expression in Synovial Fibroblasts. Signaling pathway analysis using the microarray data indicated that the expression of chemokines and IL-6 was upregulated in synovial fibroblasts by IL-17A treatment for $4 \mathrm{~h}$. We therefore next analyzed the time course of IL-17A induction of the expression of these genes in synovial fibroblasts. Their expression was analyzed using realtime PCR following incubation of synovial fibroblasts with or without IL-17A for 2, 4, 8, 12, or $24 \mathrm{~h}$. The gene expression of IL-6, CXCL1, and IL-8 (also called CXCL8) was significantly higher in synovial fibroblasts treated with IL-17A for $4 \mathrm{~h}$ to $24 \mathrm{~h}$ compared to nontreated control (Figures 4(a), 4(c), and $4(\mathrm{~d})$ ). The gene expression of CCL20 was significantly upregulated in synovial fibroblasts by IL-17A treatment for 8 to $24 \mathrm{~h}$ (Figure $4(\mathrm{~b})$ ).

3.5. Effect of IL-17A on IL-6 Protein Production in Synovial Fibroblasts. IL-6 is one of the most well-known proinflammatory cytokines implicated in the pathogenesis of various autoimmune and chronic inflammatory diseases. A number 
TABLE 2: IL-17-responsive genes in synovial fibroblasts form TMJ.

\begin{tabular}{|c|c|c|c|}
\hline Gene symbol & GenBank ID & Fold & Gene name \\
\hline \multicolumn{4}{|l|}{ Upregulated } \\
\hline \multicolumn{4}{|c|}{ Molecular function } \\
\hline \multicolumn{4}{|c|}{ Chemokine activity } \\
\hline CCL8 & NM_005623 & 51.25 & Chemokine (C-C motif) ligand 8 \\
\hline CXCL1 & NM_001511 & 49.84 & $\begin{array}{l}\text { Chemokine (C-X-C motif) ligand } 1 \text { (melanoma } \\
\text { growth stimulating activity, alpha) }\end{array}$ \\
\hline CXCL2 & NM_002089 & 38.77 & Chemokine (C-X-C motif) ligand 2 \\
\hline CXCL3 & NM_002090 & 35.88 & Chemokine (C-X-C motif) ligand 3 \\
\hline CXCL8 & NM_000584 & 24.65 & Chemokine (C-X-C motif) ligand 8 \\
\hline CCL20 & NM_004591 & 15.72 & Chemokine (C-C motif) ligand 20 \\
\hline CXCL6 & NM_002993 & 13.00 & Chemokine (C-X-C motif) ligand 6 \\
\hline CCL7 & NM_006273 & 11.10 & Chemokine (C-C motif) ligand 7 \\
\hline CCL2 & NM_002982 & 2.95 & Chemokine (C-C motif) ligand 2 \\
\hline \multicolumn{4}{|c|}{ Cytokine activity } \\
\hline AREG & NM_001657 & 3.32 & Amphiregulin \\
\hline NAMPT & AK023341 & 3.03 & Nicotinamide phosphoribosyltransferase \\
\hline BMP2 & NM_001200 & 2.96 & Bone morphogenetic protein 2 \\
\hline NDP & NM_000266 & 2.83 & Norrie disease (pseudoglioma) \\
\hline \multicolumn{4}{|c|}{ Cytokine receptor binding } \\
\hline CSF2 & NM_000758 & 17.62 & $\begin{array}{l}\text { Colony stimulating factor } 2 \\
\text { (granulocyte-macrophage) }\end{array}$ \\
\hline IL-6 & NM_000600 & 17.19 & Interleukin-6 \\
\hline CSF3 & NM_000759 & 12.62 & Colony stimulating factor 3 (granulocyte) \\
\hline LIF & NM_002309 & 5.70 & Leukemia inhibitory factor \\
\hline IL1RN & NM_173843 & 2.72 & Interleukin-1 receptor antagonist \\
\hline IL1B & NM_000576 & 2.62 & Interleukin-1, beta \\
\hline \multicolumn{4}{|c|}{ Growth factor activity } \\
\hline NTF4 & NM_006179 & 7.22 & Neurotrophin 4 \\
\hline NRG3 & NM_001010848 & 5.55 & Neuregulin 3 \\
\hline \multicolumn{4}{|c|}{ Growth factor receptor binding } \\
\hline EREG & NM_001432 & 3.18 & Epiregulin \\
\hline FRS3 & NM_006653 & 2.86 & Fibroblast growth factor receptor substrate 3 \\
\hline FGF5 & NM_033143 & 2.67 & Fibroblast growth factor 5 \\
\hline \multicolumn{4}{|c|}{ G-protein coupled receptor binding } \\
\hline ADORA2A & NM_000675 & 4.16 & Adenosine A2a receptor \\
\hline RTP1 & NM_153708 & 3.37 & Receptor (chemosensory) transporter protein 1 \\
\hline PDE4D & NM_001165899 & 2.17 & Phosphodiesterase 4D, cAMP-specific \\
\hline \multicolumn{4}{|c|}{ Receptor binding } \\
\hline EPHA7 & NM_004440 & 4.88 & EPH receptor A7 \\
\hline ICAM4 & NM_022377 & 2.77 & $\begin{array}{l}\text { Intercellular adhesion molecule } 4 \\
\text { (Landsteiner-Wiener blood group) }\end{array}$ \\
\hline STC1 & NM_003155 & 2.73 & Stanniocalcin 1 \\
\hline CD74 & NM_001025158 & 2.58 & $\begin{array}{l}\text { CD74 molecule, major histocompatibility } \\
\text { complex, class II invariant chain }\end{array}$ \\
\hline HILPDA & NM_013332 & 2.30 & Hypoxia inducible lipid droplet-associated \\
\hline EFNB2 & NM_004093 & 2.12 & Ephrin-B2 \\
\hline DOK3 & NM_024872 & 2.07 & Docking protein 3 \\
\hline PTPN2 & NM_002828 & 2.05 & Protein tyrosine phosphatase, nonreceptor type 2 \\
\hline
\end{tabular}


TABLe 2: Continued.

\begin{tabular}{|c|c|c|c|}
\hline Gene symbol & GenBank ID & Fold & Gene name \\
\hline \multicolumn{4}{|l|}{ Downregulated } \\
\hline \multicolumn{4}{|c|}{ Molecular function } \\
\hline \multicolumn{4}{|c|}{ Signaling receptor activity } \\
\hline HNF4A & NM_001030004 & -5.42 & Hepatocyte nuclear factor 4 , alpha \\
\hline CASS4 & NM_020356 & -3.21 & Cas scaffolding protein family member 4 \\
\hline NR0B1 & NM_000475 & -2.51 & Nuclear receptor subfamily 0 , group B, member 1 \\
\hline NR113 & NM_001077474 & -2.05 & Nuclear receptor subfamily 1, group I, member 3 \\
\hline \multicolumn{4}{|c|}{ Transmembrane signaling receptor activity } \\
\hline TACR1 & NM_015727 & -97.28 & Tachykinin receptor 1 \\
\hline $\mathrm{CD} 3 \mathrm{E}$ & NM_000733 & -66.90 & CD3e molecule, epsilon (CD3-TCR complex) \\
\hline OR12D2 & NM_013936 & -66.54 & $\begin{array}{l}\text { Olfactory receptor, family } 12 \text {, subfamily D, } \\
\text { member } 2\end{array}$ \\
\hline OR13J1 & NM_001004487 & -64.29 & Olfactory receptor, family 13 , subfamily J, member \\
\hline LILRB5 & NM_006840 & -57.98 & $\begin{array}{l}\text { Leukocyte immunoglobulin-like receptor, } \\
\text { subfamily B (with TM and ITIM domains), } \\
\text { member } 5\end{array}$ \\
\hline OR52N2 & NM_001005174 & -54.24 & $\begin{array}{l}\text { Olfactory receptor, family } 52 \text {, subfamily } \mathrm{N}, \\
\text { member } 2\end{array}$ \\
\hline TAS2R40 & NM_176882 & -52.34 & Taste receptor, type 2 , member 40 \\
\hline TAS2R4 & NM_016944 & -12.98 & Taste receptor, type 2 , member 4 \\
\hline CHRNA7 & NM_001190455 & -9.25 & Cholinergic receptor, nicotinic, alpha 7 (neuronal) \\
\hline TULP1 & NM_003322 & -7.60 & Tubby-like protein 1 \\
\hline
\end{tabular}

of inflammatory diseases are characterized by overproduction of IL-6. Therefore, among the IL-17A-responsive genes we selected IL- 6 to examine the effect of IL-17A on protein production. Synovial fibroblasts were incubated with concentrations of IL-17A of 1,10 , and $50 \mathrm{ng} / \mathrm{mL}$ for $24 \mathrm{~h}$. IL17A increased the IL- 6 levels in the conditioned media of synovial fibroblasts in a dose-dependent manner, although there was no significant difference between the cells treated with $1 \mathrm{ng} / \mathrm{mL}$ IL-17A and the untreated controls (Figure 5). We also examined the time course of IL- 6 protein production in synovial fibroblasts incubated with or without $10 \mathrm{ng} / \mathrm{mL}$ IL$17 \mathrm{~A}$ for $4,8,12$, or $24 \mathrm{~h}$. The IL- 6 levels in the conditioned media were increased by IL-17A in a time-dependent manner over the entire $24 \mathrm{~h}$ period (Figure 6).

In the next experiment, the effect of IL-17A on IL6 protein production in three synovial fibroblasts samples isolated from three different patients was examined. IL-6 protein levels were significantly increased in the conditioned media from the cells treated with $10 \mathrm{ng} / \mathrm{mL}$ IL-17A for $24 \mathrm{~h}$ compared to the untreated control cells in all three samples, although the level of the increase varied among the individual three samples (Figure 7).

3.6. Effect of Signaling Inhibitors on IL-17A-Induced IL-6 Production by Synovial Fibroblasts. The network of IPA and several previous reports suggested that cytokine expression induced by IL-17A is mediated via $\mathrm{NF} \kappa \mathrm{B}$. We therefore investigated the effects of inhibitors of the $\mathrm{NF} \kappa \mathrm{B}$ signaling pathway on IL-17A-induced IL-6 production by synovial fibroblasts. The induction of IL-6 by IL-17A was decreased in synovial fibroblasts by pretreatment with LY294002 (a PI3K inhibitor), (5z)-7-Oxozeaenol (a TAK1 inhibitor), and PS-1145 (an IKK $\beta$ inhibitor); in contrast, its production was not affected by an IRAK-1/4 inhibitor (Figure 8). IL6 production was inhibited by $35.0 \%$ by LY294002, by $95.7 \%$ by (5z)-7-Oxozeaenol, and by $21.2 \%$ by PS- 1145 (Figure 8).

\section{Discussion}

The current studies demonstrated that IL-17A plays an important role as a proinflammatory cytokine in autoimmune diseases and in chronic inflammatory diseases such as rheumatoid arthritis. To elucidate the roles of IL-17A in inflammatory progression of TMD, we isolated synovial fibroblasts from patients with TMD and examined the gene expression profiles in synovial fibroblasts treated with IL17A. Prior to undertaking analysis of these gene expression profiles we first checked the ability of these cells to transduce IL-17 signals by confirming the expression of IL-17Rs in synovial fibroblasts; all of the IL-17 receptors were found to be expressed in synovial fibroblasts. In recent studies, a polymorphism in the IL-17RC was reported to be associated with the different splice variants observed in several cell types $[25,26]$. In this study, the IL-17RC PCR product was visualized as two bands by agarose gel electrophoresis; thus there may be more than two different splicing variants of the IL-17RC in synovial fibroblasts. 
IL-17 and rheumatoid arthritis

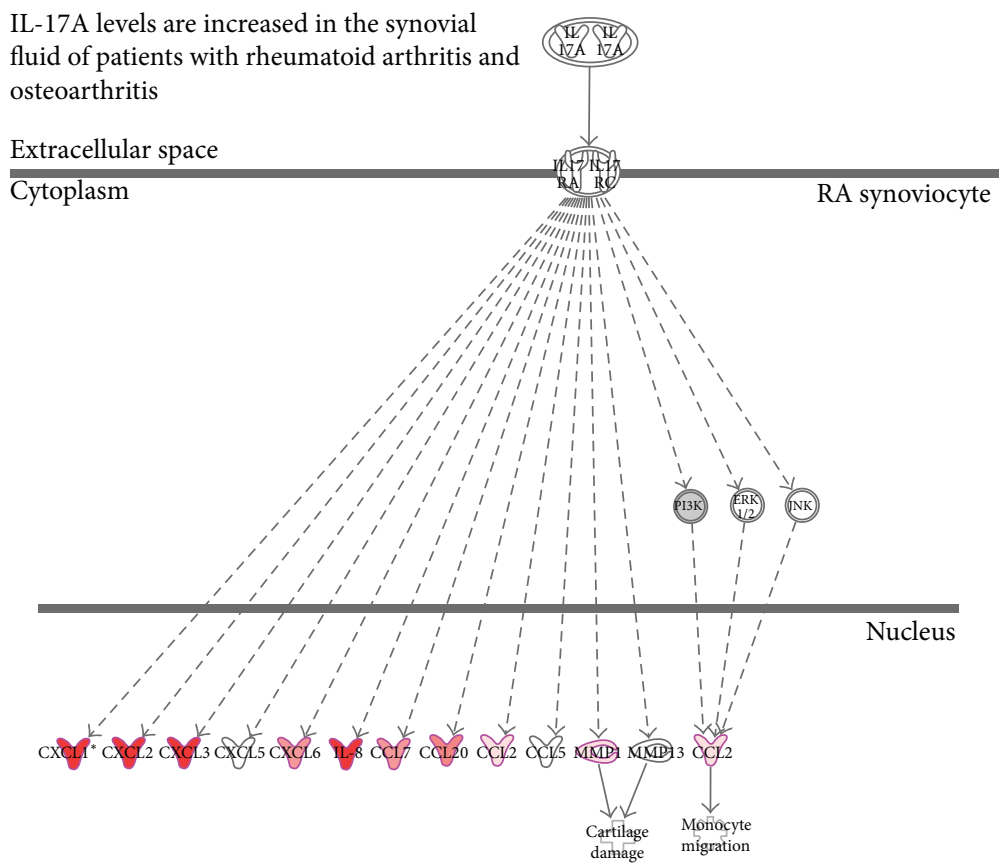

(a)

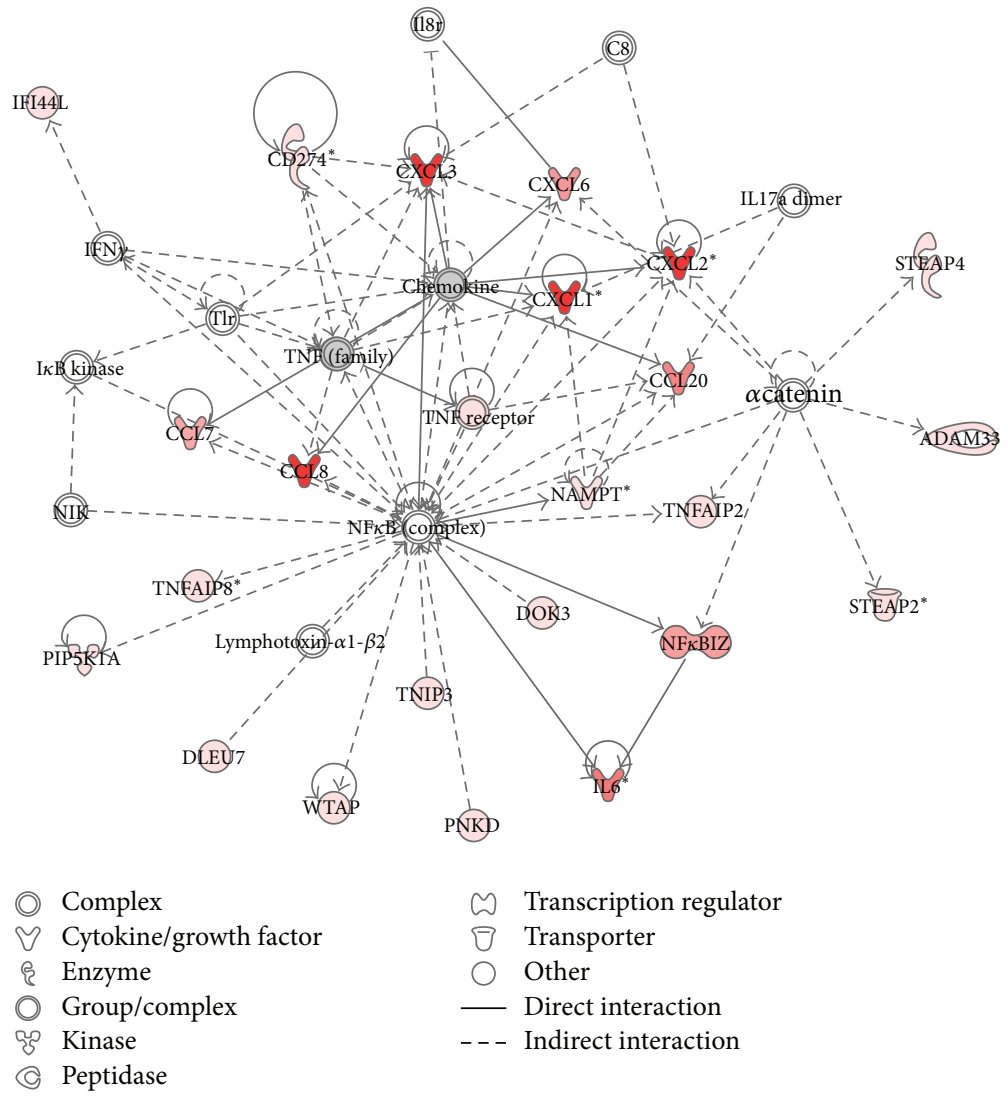

(b)

Figure 3: Network of the IL-17A pathway by Ingenuity Pathway Analysis (IPA). Data were analyzed using the Ingenuity Pathway Analysis system (Ingenuity System, http://www.ingenuity.com/). (a) IL-17A-induced genes associated with rheumatoid arthritis. (b) Network 1 of IL$17 \mathrm{~A}$-induced genes by IPA. The intensity of the node color indicates the degree of upregulation (red). Nodes are indicated by various shapes that represent the functional class of the gene product. The lines are displayed with various labels that describe the nature of the relationship between the nodes. 
IL-6

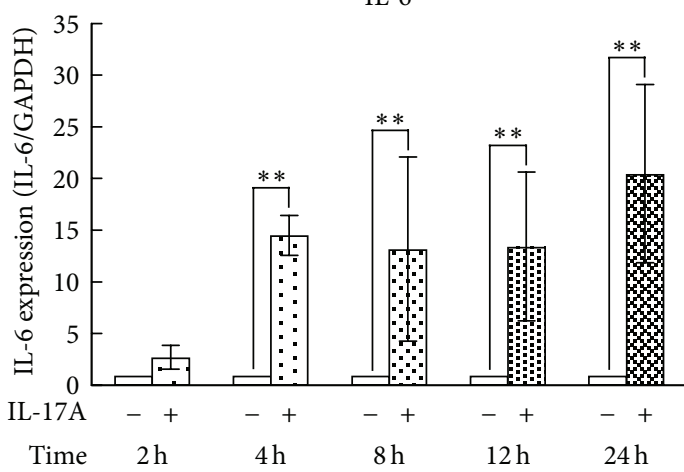

(a)

CXCL1

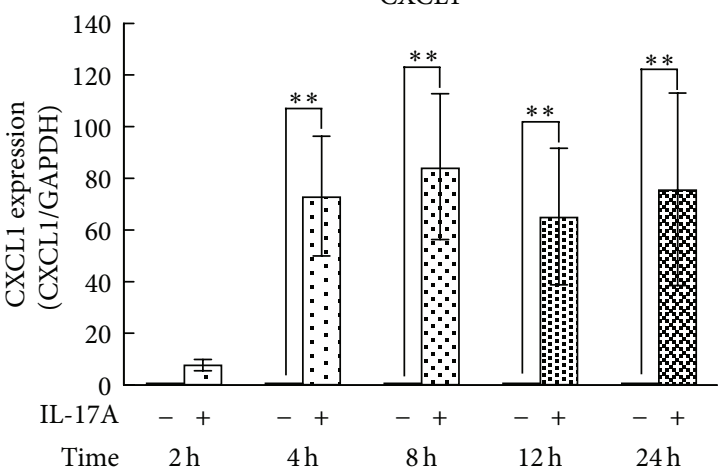

(c)

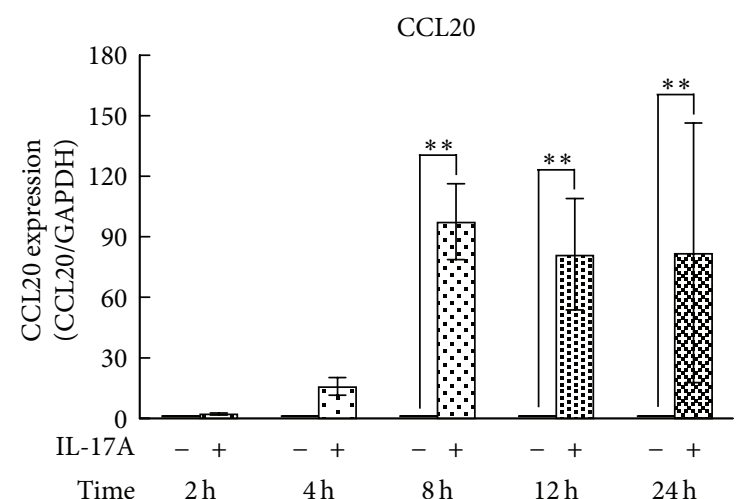

(b)

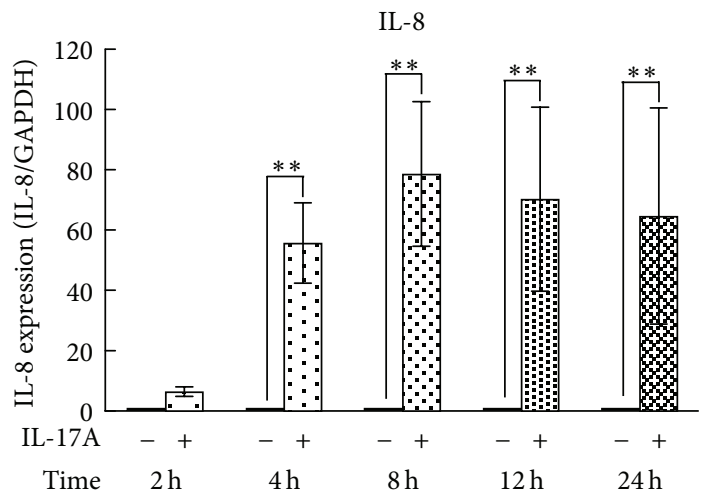

(d)

Figure 4: Time course of IL-17A induction of the mRNA expression of IL-6, CCL20, CXCL1, and IL-8 in synovial fibroblasts. The effect of IL-17A on (a) IL-6, (b) CCL20, (c) CXCL1, and (d) IL-8 gene expression in synovial fibroblasts was analyzed using real-time PCR following culture of the cells with or without IL-17A $(10 \mathrm{ng} / \mathrm{mL})$ for $4,8,12$, or $24 \mathrm{~h}$. Data are shown as means $\pm \operatorname{SD}(n=5) ;{ }^{* *} P<0.01$.

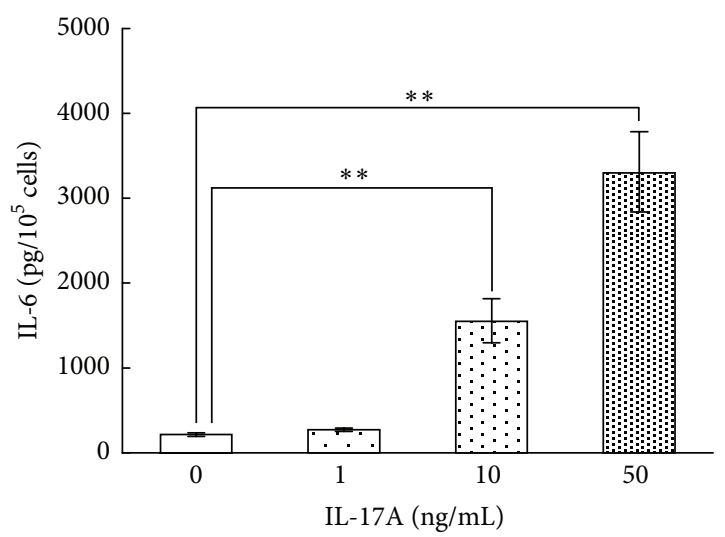

FigURE 5: Effects of IL-17A on IL-6 protein production by synovial fibroblasts. Synovial fibroblasts were treated with the indicated concentrations of IL-17A for $24 \mathrm{~h}$. The IL- 6 protein levels in the conditioned medium were then assayed using ELISA. Data are shown as means $\pm \mathrm{SD}(n=6) ;{ }^{* *} P<0.01$.

Using a high throughput DNA microarray, a total of 1,710 genes showed a greater than twofold difference in expression intensity between nontreated control and IL-17A-treated synovial fibroblasts. We also investigated the biological

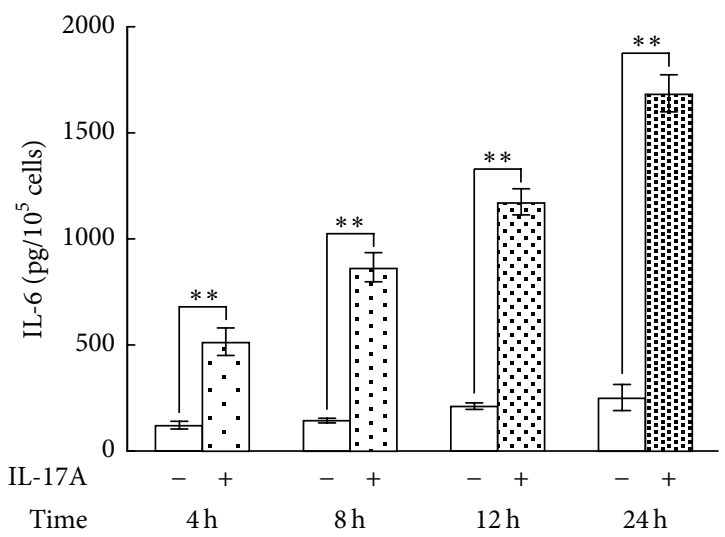

Figure 6: Time course of IL-17A-induced IL-6 production by synovial fibroblasts. Synovial fibroblasts were treated with $10 \mathrm{ng} / \mathrm{mL}$ IL-17A for 4, 8, 12, or $24 \mathrm{~h}$. The IL-6 protein levels in the conditioned medium were then assayed using ELISA. Data are shown as means $\pm \mathrm{SD}(n=6) ;{ }^{* *} P<0.01$.

functions and the molecular interactions of these IL-17Aresponsive genes using signaling pathway analysis. Many of the responsive genes can be associated with "inflammatory response" and "immunological disease." IL-17A upregulated 


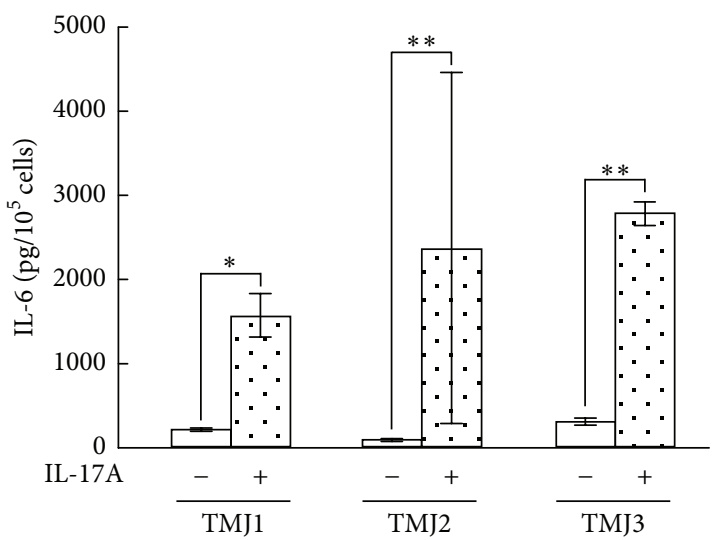

FIGURE 7: Effect of IL-17A on IL-6 production by three human synovial fibroblast samples. Synovial fibroblast samples were isolated from three patients with TMD (TMJ1-3). The cells were treated with $10 \mathrm{ng} / \mathrm{mL}$ IL-17A for $24 \mathrm{~h}$, following which the IL-6 protein levels in the conditioned medium were then assayed using ELISA. Data are shown as means $\pm \mathrm{SD}(n=6) ;{ }^{*} P<0.05 ;{ }^{* *} P<0.01$.

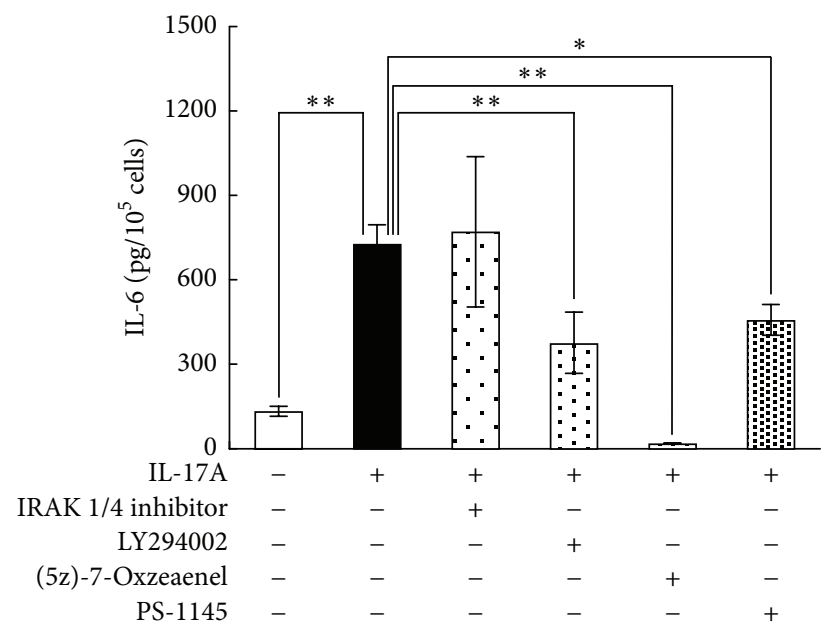

FIGURE 8: Effect of inhibitors of the NF $\kappa \mathrm{B}$ signaling pathway on IL-17A-induced IL-6 production by synovial fibroblasts. Synovial fibroblasts were pretreated with the IRAK $1 / 4$ inhibitor $(20 \mu \mathrm{M})$, $20 \mu \mathrm{M}$ LY294002, $1 \mu \mathrm{M}$ (5z)-7-Oxozeaenol, or $10 \mu \mathrm{M}$ PS-1145 for $30 \mathrm{~min}$ and were then treated with $10 \mathrm{ng} / \mathrm{mL}$ IL-17A for $8 \mathrm{~h}$, following which the IL-6 protein levels in the conditioned medium were assayed using ELISA. Results are expressed as means $\pm \operatorname{SD}(n=4)$; ${ }^{*} P<0.05 ;{ }^{* *} P<0.01$.

the expression of numerous chemokine superfamily members that are involved in regulation of leukocyte accumulation and activation in inflammatory tissues. In this study, we examined the kinetics of the expression of CXCL1, IL-8, and CCL20 using real-time PCR. The gene expression of CXCL1 (also called Gro- $\alpha$ ) and IL-8 (also called CXCL8), which are well-known chemokines, was highly upregulated by IL-17A. On the other hand, it has been reported that CCL20 (also called MIP-3 $\alpha$ ) functions as a chemoattractant for Th17 producing IL-17 cells [27]. The IL-17A-induced expression of CXCL1, IL-8, and CCL20 in synovial fibroblasts was maintained for $24 \mathrm{~h}$. It has been reported that one key property of IL-17A is its role in orchestrating the migration of inflammatory cells, which has a central place in RA pathogenesis [28]. Since inflammatory cells have been detected in synovial tissue and fluid from patients with TMD [29, 30], IL17A may therefore have a role in inducing inflammation such as in leukocyte attraction in TMD. In addition, the migration of Th17 cells induced by CCL20 that is produced by synovial fibroblasts may cause the increase in IL-17A levels in synovial tissue in TMD.

The mRNA expression of IL-6 was also upregulated in synovial fibroblasts by IL-17A, and its protein production was increased in IL-17A time- and dose-dependent manner. IL-17A also stimulated IL-6 protein production in all three synovial fibroblasts samples isolated from the three patients. IL- 6 has an important role in inflammation and tissue destruction in joint diseases such as RA [31], and its concentration is elevated in the synovial fluids of arthritic patients [32, 33]. IL-6 was shown to have an important role in inflammation-evoked osteoclast formation and bone erosion [34]. It was recently demonstrated that IL-6 can promote Th17 cell differentiation in effector CD4+ $\mathrm{T}$ cell subsets [35]. This function of IL-6 is through to play a major role in the development of RA [36]. In TMD, the IL-6 level was also increased in synovial fluid from patients with ID and/or OA $[22,37]$. The excessive production of IL-6 in synovial fibroblasts by IL-17A thus appears to be related to abnormalities associated with TMD.

Signaling pathway analysis also indicated that the expression of chemokine and IL- 6 was stimulated by $\mathrm{NF} \kappa \mathrm{B}$. IL$17 \mathrm{~A}$ signals through a heterodimeric receptor complex of IL17RA and IL-17RC [14], leading to activation of $N F \kappa B$ in several cell types $[38,39]$. It is generally believed that IL-17 signalingshares downstream transcription factors with IL-1 $\beta$ and TNF- $\alpha$ [40]. Previous studies have reported that IL-17 appears to exert an additive and synergistic effect with IL$1 \beta$ and TNF- $\alpha$ as inducers of IL- 6 in RA synovium [41]. We suspected that the majority of genes that were upregulated by IL-17A may be similar to those that are upregulated by IL- $1 \beta$ and TNF- $\alpha$. We have previously investigated the gene expression profiles in TMJ synovial fibroblasts treated with IL- $1 \beta$ and/or TNF- $\alpha[42,43]$. To investigate IL-17A-mediated $\mathrm{NF} \kappa \mathrm{B}$ activation, we examined the effects of inhibitors of $\mathrm{NF} \kappa \mathrm{B}$ signaling on IL-6 production in synovial fibroblasts treated with IL-17A. We found that IL-17A-induced IL-6 production was inhibited by LY294002 (a PI3K inhibitor), (5z)-7-Oxozeaenol (a TAK1 inhibitor), and PS-1145 (an IKK $\beta$ inhibitor) but was not affected by an IRAK-1/4 inhibitor. Therefore IL-17A signal transduction may share TAK1 and its downstream signals leading to $\mathrm{NF} \kappa \mathrm{B}$ activation with IL-1 $\beta$ signal transduction. In addition, PI3K/Akt signaling, which is involved in TNF- $\alpha$-dependent NF $\kappa$ B activation [44], was also associated with IL-17A-induced IL-6 production by synovial fibroblasts. However, inhibition of IL-6 production by the TAK1 inhibitor was stronger than that by the IKK $\beta$ inhibitor. It has been reported that TAK1 signaling is mediated by several other signaling transduction pathways, such as MAPK signaling pathways, in addition to $\mathrm{NF} \kappa \mathrm{B}$ activation [45]. Furthermore, PI3K/Akt promotes survival by 


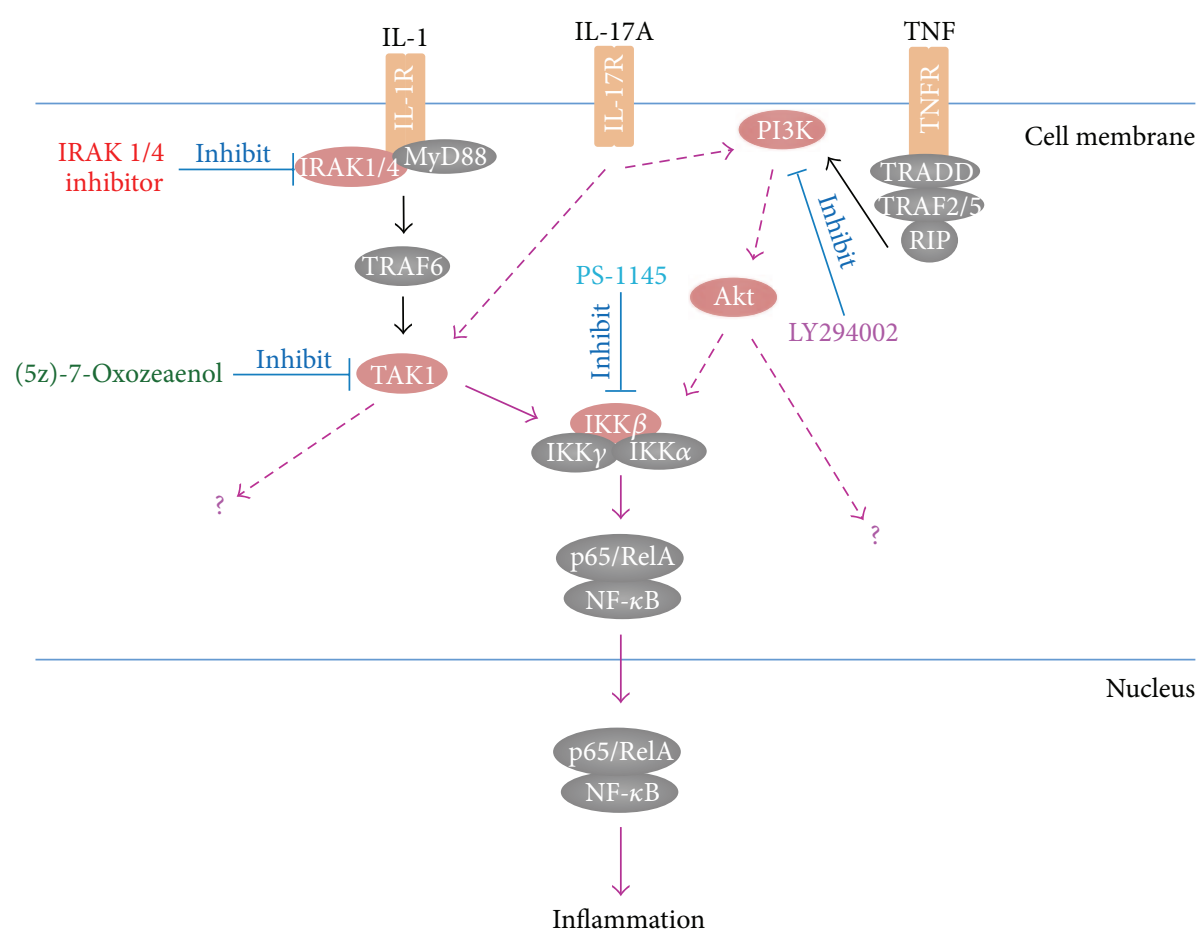

FIgURE 9: The signaling pathways of IL-17A in synovial fibroblasts. The scheme shows activation of the NF $\kappa$ B signaling pathway through IL-17A and shared signaling with IL-1 and TNF. The purple arrows indicate signal transduction through IL-17A.

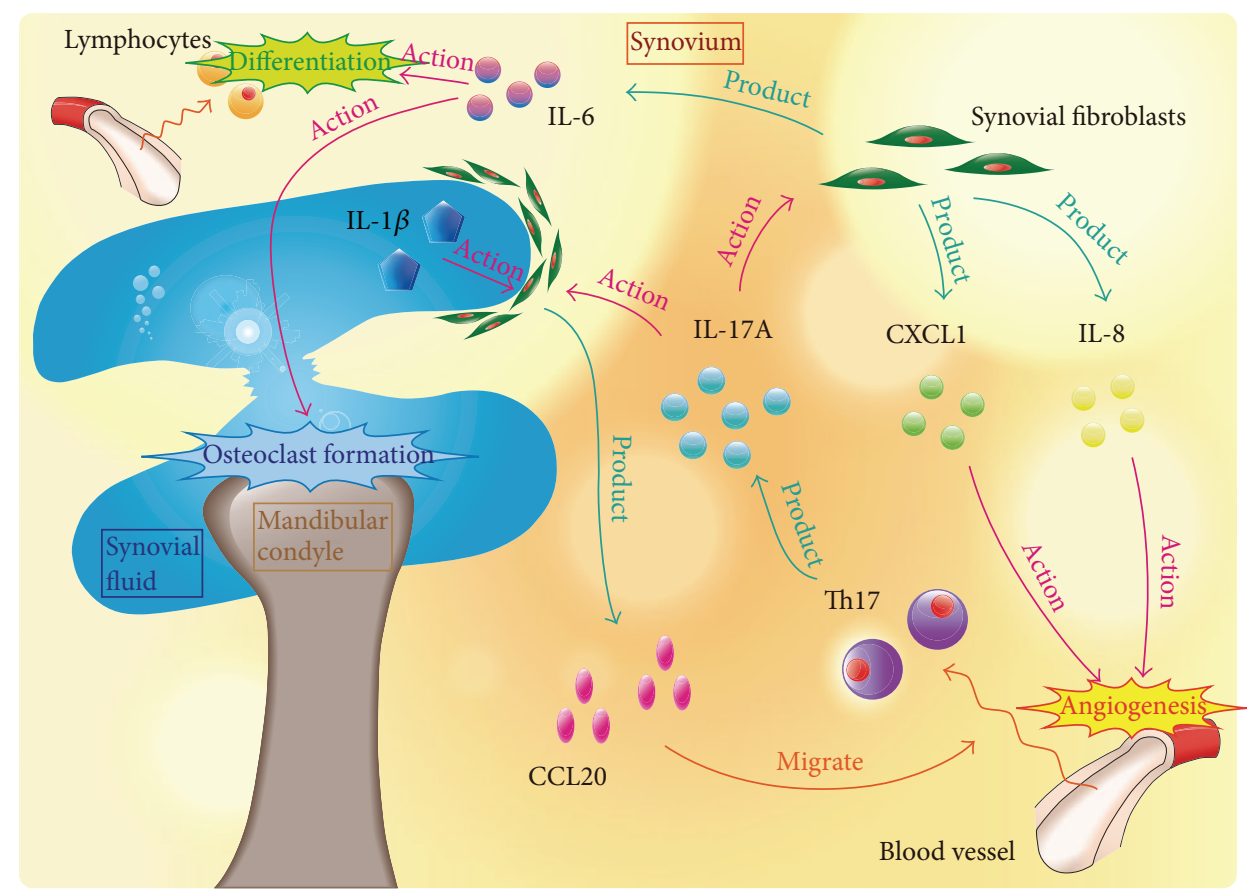

FIGURE 10: Summary of the TMJ inflammatory condition mediated by IL-17A.

inhibiting p53 and Bak/Bax-mediated apoptosis and triggering AP1 activation [46]. We therefore suggest that IL-17A activates several signaling pathways other than the $\mathrm{NF} \kappa \mathrm{B}$ activation pathway for IL-6 production in synovial fibroblasts (Figure 9).
In this study, our findings demonstrated that IL-17A upregulation of the expression of IL- 6 and chemokines that is mediated by the $\mathrm{NF} \kappa \mathrm{B}$ pathway is important in promoting leukocyte attraction to and invasion of the synovial tissue of TMD (Figure 10). We suggest that this IL-17A cascade is 
likely to contribute to the promotion of and to increase the inflammatory condition in TMD.

\section{Conclusions}

All IL-17 receptors are expressed in the synovial fibroblasts of TMJ. IL-17A induces the mRNA expression of chemokines and IL-6, as well as the protein production of IL-6 in synovial fibroblasts. IL-17A appears to transduce signals for IL-6 production via activation of $\mathrm{NF} \kappa \mathrm{B}$ and $\mathrm{PI} 3 \mathrm{~K} / \mathrm{Akt}$ pathways. Our data provide insights into the cellular mechanisms by which IL-17A participates in the activation of synovial fibroblasts in the inflamed temporomandibular joint.

\section{Conflict of Interests}

The authors declare that there is no conflict of interests regarding the publication of this paper.

\section{Acknowledgment}

This study was supported by Grants-in-Aid for Scientific Research (c) (22592230 and 26463026) from the Japan Society for the Promotion of Science.

\section{References}

[1] F. R. Carls, A. von Hochstetter, M. Makek, and W. Engelke, "Diagnostic accuracy of TMJ arthroscopy in correlation to histological findings," Journal of Cranio-Maxillofacial Surgery, vol. 23, no. 2, pp. 75-80, 1995.

[2] L. C. Dijkgraaf, R. S. B. Liem, and L. G. M. de Bont, "Synovial membrane involvement in osteoarthritic temporomandibular joints: a light microscopic study," Oral Surgery, Oral Medicine, Oral Pathology, Oral Radiology, and Endodontics, vol. 83, no. 3, pp. 373-386, 1997.

[3] G. W. Gynther, A. B. Holmlund, F. P. Reinholt, and S. Lindblad, "Temporomandibular joint involvement in generalized osteoarthritis and rheumatoid arthritis: a clinical, arthroscopic, histologic, and immunohistochemical study," International Journal of Oral and Maxillofacial Surgery, vol. 26, no. 1, pp. 1016, 1997.

[4] H. A. Israel, C.-J. Langevin, M. D. Singer, and D. A. Behrman, "The relationship between temporomandibular joint synovitis and adhesions: pathogenic mechanisms and clinical implications for surgical management," Journal of Oral and Maxillofacial Surgery, vol. 64, no. 7, pp. 1066-1074, 2006.

[5] H. A. Israel, B. Diamond, F. Saed-Nejad, and A. Ratcliffe, "Osteoarthritis and synovitis as major pathoses of the temporomandibular joint: comparison of clinical diagnosis with arthroscopic morphology," Journal of Oral and Maxillofacial Surgery, vol. 56, no. 9, pp. 1023-1027, 1998.

[6] R. Kardel, A.-K. Ulfgren, F. P. Reinholt, and A. Holmlund, "Inflammatory cell and cytokine patterns in patients with painful clicking and osteoarthritis in the temporamandibular joint," International Journal of Oral and Maxillofacial Surgery, vol. 32, no. 4, pp. 390-396, 2003.

[7] G. W. Gynther, L. C. Dijkgraaf, F. P. Reinholt, A. B. Holmlund, R. S. B. Liem, and L. G. M. De Bont, "Synovial inflammation in arthroscopically obtained biopsy specimens from the temporomandibular joint: a review of the literature and a proposed histologic grading system," Journal of Oral and Maxillofacial Surgery, vol. 56, no. 11, pp. 1281-1286, 1998.

[8] J. E. Chin, G. E. Winterrowd, R. F. Krzesicki, and M. E. Sanders, "Role of cytokines in inflammatory synovitis: the coordinate regulation of intercellular adhesion molecule 1 and HLA class I and class II antigens in rheumatoid synovial fibroblasts," Arthritis and Rheumatism, vol. 33, no. 12, pp. 1776-1786, 1990.

[9] S. Kyung Chang, Z. Gu, and M. B. Brenner, "Fibroblast-like synoviocytes in inflammatory arthritis pathology: the emerging role of cadherin-11," Immunological Reviews, vol. 233, no. 1, pp. 256-266, 2010.

[10] C. D. Buckley, "Why does chronic inflammation persist: an unexpected role for fibroblasts," Immunology Letters, vol. 138, no. 1, pp. 12-14, 2011.

[11] Z. Yao, S. L. Painter, W. C. Fanslow et al., "Human IL-17: a novel cytokine derived from T cells," The Journal of Immunology, vol. 155, no. 12, pp. 5483-5486, 1995.

[12] P. Miossec, "IL-17 and Th17 cells in human inflammatory diseases," Microbes and Infection, vol. 11, no. 5, pp. 625-630, 2009.

[13] T. A. Moseley, D. R. Haudenschild, L. Rose, and A. H. Reddi, "Interleukin-17 family and IL-17 receptors," Cytokine and Growth Factor Reviews, vol. 14, no. 2, pp. 155-174, 2003.

[14] S. H. Chang and C. Dong, "IL-17F: regulation, signaling and function in inflammation," Cytokine, vol. 46, no. 1, pp. 7-11, 2009.

[15] S. A. Metawi, D. Abbas, M. M. Kamal, and M. K. Ibrahim, "Serum and synovial fluid levels of interleukin-17 in correlation with disease activity in patients with RA," Clinical Rheumatology, vol. 30, no. 9, pp. 1201-1207, 2011.

[16] B. Chen, Y. Deng, Y. Tan, J. Qin, and L.-B. Chen, "Association between severity of knee osteoarthritis and serum and synovial fluid interleukin 17 concentrations," The Journal of International Medical Research, vol. 42, no. 1, pp. 138-144, 2014.

[17] E. M. Moran, R. Mullan, J. McCormick et al., "Human rheumatoid arthritis tissue production of IL-17A drives matrix and cartilage degradation: Synergy with tumour necrosis factor$\alpha$, Oncostatin $\mathrm{M}$ and response to biologic therapies," Arthritis Research \& Therapy, vol. 11, no. 4, article R113, 2009.

[18] M.-L. Toh, G. Gonzales, M. I. Koenders et al., "Role of interleukin 17 in arthritis chronicity through survival of synoviocytes via regulation of synoviolin expression," PLoS ONE, vol. 5, no. 10, Article ID e13416, 2010.

[19] G.-Q. Li, Y. Zhang, D. Liu et al., "Celastrol inhibits interleukin17A-stimulated rheumatoid fibroblast-like synoviocyte migration and invasion through suppression of NF- $\kappa$ B-mediated matrix metalloproteinase-9 expression," International Immunopharmacology, vol. 14, no. 4, pp. 422-431, 2012.

[20] Y. Chen, M. Zhong, L. Liang, F. Gu, and H. Peng, "Interleukin17 induces angiogenesis in human choroidal endothelial cells in vitro," Investigative Ophthalmology \& Visual Science, vol. 55, no. 10, pp. 6968-6975, 2014.

[21] S. Nakae, A. Nambu, K. Sudo, and Y. Iwakura, "Suppression of immune induction of collagen-induced arthritis in IL-17deficient mice," The Journal of Immunology, vol. 171, no. 11, pp. 6173-6177, 2003.

[22] K. Kaneyama, N. Segami, J. Sato, M. Nishimura, and H. Yoshimura, "Interleukin-6 family of cytokines as biochemical markers of osseous changes in the temporomandibular joint disorders," 
British Journal of Oral and Maxillofacial Surgery, vol. 42, no. 3, pp. 246-250, 2004.

[23] N. Ogura, M. Tobe, H. Sakamaki et al., "Interleukin-1 $\beta$ induces interleukin- 6 mRNA expression and protein production in synovial cells from human temporomandibular joint," Journal of Oral Pathology and Medicine, vol. 31, no. 6, pp. 353-360, 2002.

[24] K. J. Livak and T. D. Schmittgen, "Analysis of relative gene expression data using real-time quantitative PCR and the $2^{-\Delta \Delta C_{T}}$ method," Methods, vol. 25, no. 4, pp. 402-408, 2001.

[25] D. R. Haudenschild, S. B. Curtiss, T. A. Moseley, and A. H. Reddi, "Generation of interleukin-17 receptor-like protein (IL17RL) in prostate by alternative splicing of RNA," The Prostate, vol. 66, no. 12, pp. 1268-1274, 2006.

[26] S. Zhou, X.-S. Qiu, Z.-Z. Zhu, W.-F. Wu, Z. Liu, and Y. Qiu, "A single-nucleotide polymorphism rs708567 in the IL-17RC gene is associated with a susceptibility to and the curve severity of adolescent idiopathic scoliosis in a Chinese Han population: a case-control study," BMC Musculoskeletal Disorders, vol. 13, article 181, 2012.

[27] T. Mabuchi, T. W. Chang, S. Quinter, and S. T. Hwang, "Chemokine receptors in the pathogenesis and therapy of psoriasis," Journal of Dermatological Science, vol. 65, no. 1, pp. 4-11, 2012.

[28] E. M. Moran, M. Connolly, W. Gao, J. McCormick, U. Fearon, and D. J. Veale, "Interleukin-17A induction of angiogenesis, cell migration, and cytoskeletal rearrangement," Arthritis \& Rheumatism, vol. 63, no. 11, pp. 3263-3273, 2011.

[29] K. Fu, X. Ma, Z. Zhang, X. Pang, and W. Chen, "Interleukin6 in synovial fluid and HLA-DR expression in synovium from patients with temporomandibular disorders," Journal of Orofacial Pain, vol. 9, no. 2, pp. 131-137, 1995.

[30] J. Sato, N. Segami, M. Nishimura et al., "Expression of interleukin 6 in synovial tissues in patients with internal derangement of the temporomandibular joint," British Journal of Oral and Maxillofacial Surgery, vol. 41, no. 2, pp. 95-101, 2003.

[31] G. W. Kim, N. R. Lee, R. H. Pi et al., "IL-6 inhibitors for treatment of rheumatoid arthritis: past, present, and future," Archives of Pharmacal Research, vol. 38, no. 5, pp. 575-584, 2015.

[32] N. G. Arvidson, B. Gudbjornsson, L. Elfman, A.-C. Ryden, T. H. Totterman, and R. Hallgren, "Circadian rhythm of serum interleukin-6 in rheumatoid arthritis," Annals of the Rheumatic Diseases, vol. 53, no. 8, pp. 521-524, 1994.

[33] P. Silacci, J.-M. Dayer, A. Desgeorges, R. Peter, C. Manueddu, and P.-A. Guernet, "Interleukin (IL)-6 and its soluble receptor induce TIMP-1 expression in synoviocytes and chondrocytes, and block IL-1-induced collagenolytic activity," The Journal of Biological Chemistry, vol. 273, no. 22, pp. 13625-13629, 1998.

[34] R. Axmann, C. Böhm, G. Krönke, J. Zwerina, J. Smolen, and G. Schett, "Inhibition of interleukin-6 receptor directly blocks osteoclast formation in vitro and in vivo," Arthritis and Rheumatism, vol. 60, no. 9, pp. 2747-2756, 2009.

[35] A. Kimura and T. Kishimoto, "IL-6: regulator of Treg/Th17 balance," European Journal of Immunology, vol. 40, no. 7, pp. 1830-1835, 2010.

[36] T. Korn, E. Bettelli, M. Oukka, and V. K. Kuchroo, "IL-17 and Th17 cells," Annual Review of Immunology, vol. 27, pp. 485-517, 2009.

[37] M. Nishimura, N. Segami, K. Kaneyama, T. Suzuki, and M. Miyamaru, "Proinflammatory cytokines and arthroscopic findings of patients with internal derangement and osteoarthritis of the temporomandibular joint," British Journal of Oral and Maxillofacial Surgery, vol. 40, no. 1, pp. 68-71, 2002.
[38] G. Li, Y. Zhang, Y. Qian et al., "Interleukin-17A promotes rheumatoid arthritis synoviocytes migration and invasion under hypoxia by increasing MMP2 and MMP9 expression through NF- $\kappa$ B/HIF- $1 \alpha$ pathway," Molecular Immunology, vol. 53 , no. 3, pp. 227-236, 2013.

[39] G. Elain, K. Jeanneau, A. Rutkowska, A. K. Mir, and K. K. Dev, "The selective anti-IL17A monoclonal antibody secukinumab (AIN457) attenuates IL17A-induced levels of IL6 in human astrocytes," Glia, vol. 62, no. 5, pp. 725-735, 2014.

[40] S.-Y. Hwang, J.-Y. Kim, K.-W. Kim et al., "IL-17 induces production of IL- 6 and IL-8 in rheumatoid arthritis synovial fibroblasts via NF-kappaB- and PI3-kinase/Akt-dependent pathways," Arthritis Research \& Therapy, vol. 6, no. 2, pp. R120-R128, 2004.

[41] Y. Katz, O. Nadiv, and Y. Beer, "Interleukin-17 enhances tumor necrosis factor alpha-induced synthesis of interleukins 1,6, and 8 in skin and synovial fibroblasts: a possible role as a 'fine-tuning cytokine' in inflammation processes," Arthritis and Rheumatism, vol. 44, no. 9, pp. 2176-2184, 2001.

[42] N. Ogura, M. Akutsu, M. Tobe, H. Sakamaki, Y. Abiko, and T. Kondoh, "Microarray analysis of IL-1 $\beta$-stimulated chemokine genes in synovial fibroblasts from human TMJ," Journal of Oral Pathology and Medicine, vol. 36, no. 4, pp. 223-228, 2007.

[43] M. Akutsu, N. Ogura, K. Ito, M. Kawashima, T. Kishida, and T. Kondoh, "Effects of interleukin- $1 \beta$ and tumor necrosis factor$\alpha$ on macrophage inflammatory protein $-3 \alpha$ production in synovial fibroblast-like cells from human temporomandibular joints," Journal of Oral Pathology and Medicine, vol. 42, no. 6, pp. 491-498, 2013.

[44] J.-B. Huang, Y. Ding, D.-S. Huang et al., "Inhibition of the $\mathrm{PI} 3 \mathrm{~K} / \mathrm{AKT}$ pathway reduces tumor necrosis factor-alpha production in the cellular response to wear particles in vitro," Artificial Organs, vol. 37, no. 3, pp. 298-307, 2013.

[45] M. C. Walsh, G. K. Kim, P. L. Maurizio, E. E. Molnar, and Y. Choi, "TRAF6 autoubiquitination-independent activation of the NF $\kappa$ B and MAPK pathways in response to IL-1 and RANKL," PLoS ONE, vol. 3, no. 12, Article ID e4064, 2008.

[46] P. Escoll, I. Ranz, N. Muñoz-Antón et al., "Sustained interleukin- $1 \beta$ exposure modulates multiple steps in glucocorticoid receptor signaling, promoting split-resistance to the transactivation of prominent anti-inflammatory genes by glucocorticoids," Mediators of Inflammation, vol. 2015, Article ID 347965, 16 pages, 2015. 


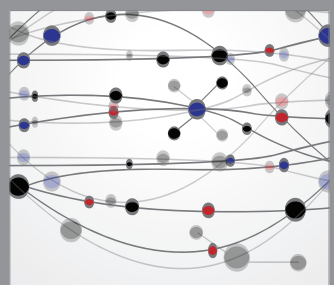

The Scientific World Journal
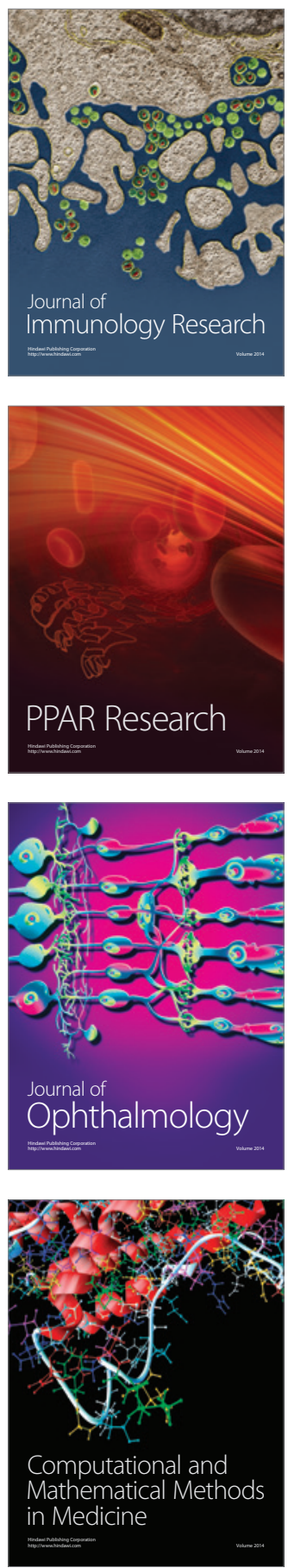

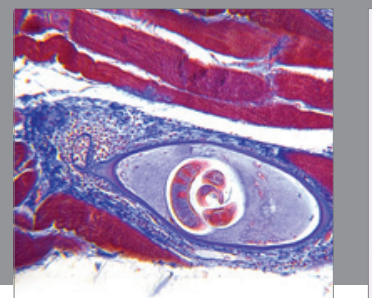

Gastroenterology

Research and Practice
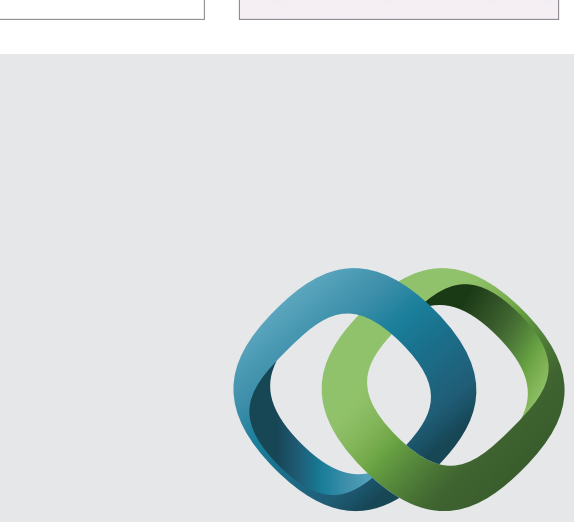

\section{Hindawi}

Submit your manuscripts at

http://www.hindawi.com
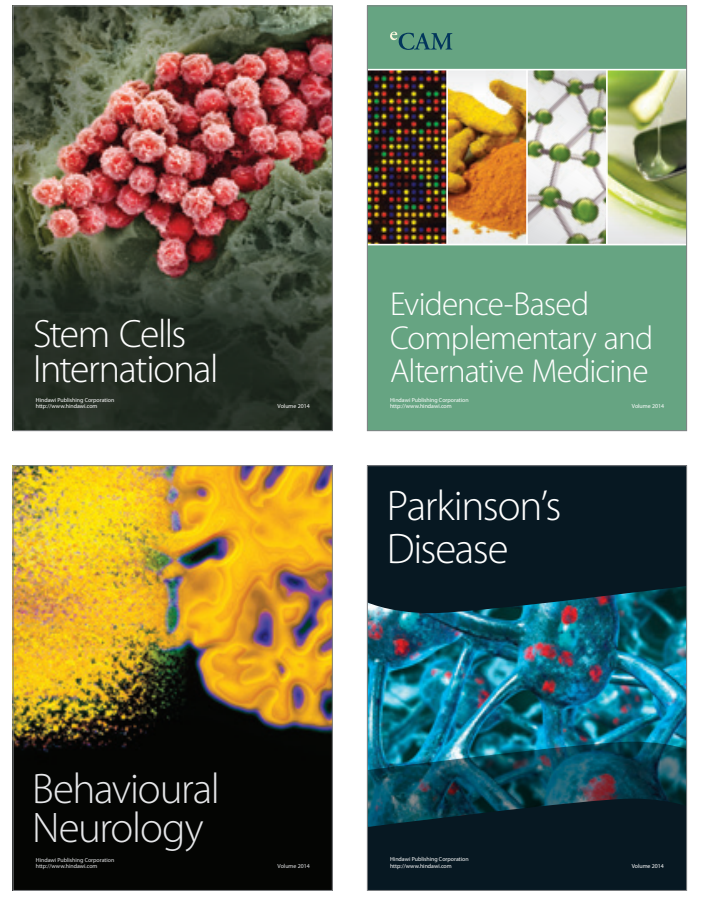
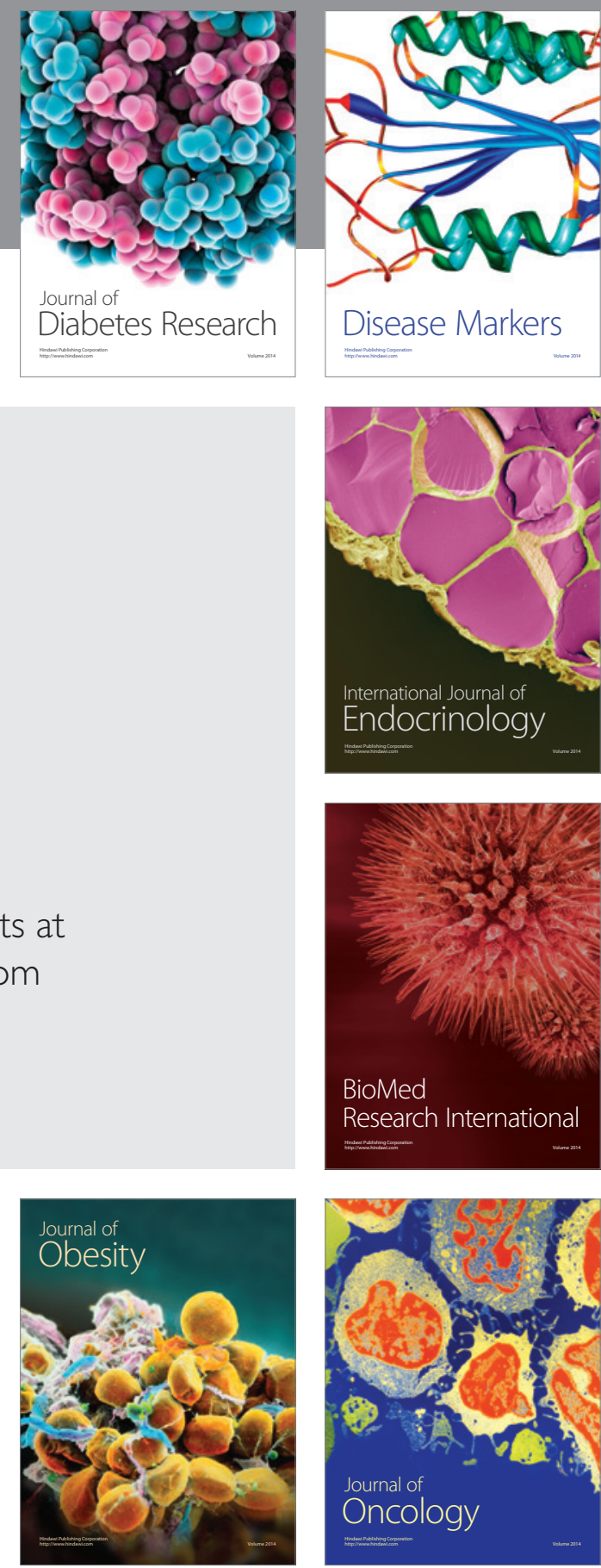

Disease Markers
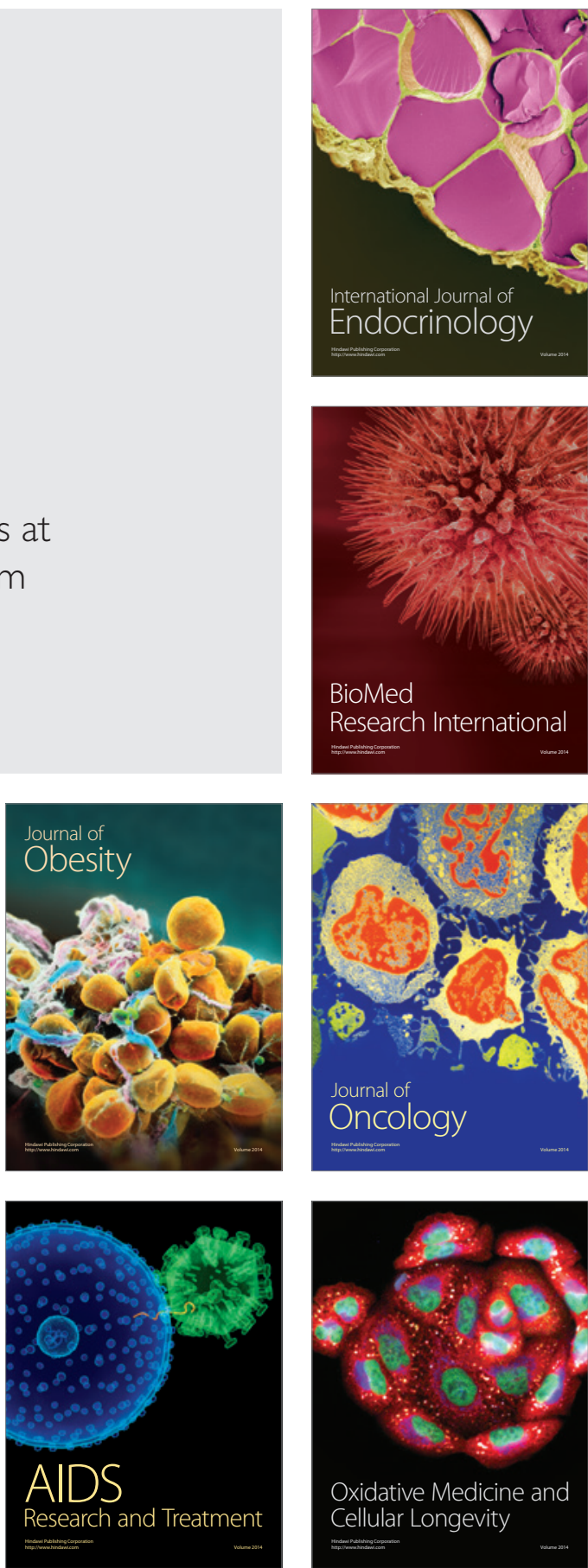